\title{
The Genetic and Morphoagronomy Character Diversity of Black Soybean Plant (Glycine soja (L.)): Responses to Mutation Induction by Gamma Rays Irradiation and Ethyl Methane Sulfonate
}

\author{
Shaddiqah Munawaroh Fauziah ${ }^{* 1}$, Evika Sandi Savitri², Estri Laras Arumingtyas ${ }^{3}$ \\ ${ }^{1}$ Department of Biology, Facultyof Mathematics and Natural Sciences, University of Brawijaya, Malang, Indonesia \\ 2UIN Maulana Malik Ibrahim Malang, Department of Biology, Faculty of Science and Technology, Malang, Indonesia \\ ${ }^{3}$ Department of Biology, Faculty of Mathematics and Natural Sciences, University of Brawijaya, Malang, Indonesia
}

\begin{abstract}
Indonesia has a high dependence on imports of black soybeans. National black soybean needs continue to increase. Therefore, some efforts are needed to increase soybean production. Genetic resources of Black Soybeans with high diversity is also needed to develop superior varieties. One of the ways to increase soybean production is by mutation induction. Therefore, genetic resources of Black Soybeans with high diversity is needed to develop superior varieties. Mutagenesis using gamma rays and EMS can be used to increase genetic diversity. Doses used in this research were 1000 Gy gamma rays, 1\% EMS, and combinations. This research was using a completely randomized design with morphoargonomy and molecular parameters. Morphoagronomy parameters observed were plant height, leaf area, seed weight, number of leaves, number of pods, and number of branches. ISSR markers with four primers (UBC 888 , ISSR3, UBC876, and UBC889) were used to determine genetic variation of Black Soybeans. Based on the analysis of variance (ANOVA), it was shown that all parameters were able to give an effect on the morphoagronomy of black soybean plants. Gamma rays $1000 \mathrm{~Gy}$ were more effective in improving morphoagronomy of the plant in terms of plant height, seed weight, number of leaves, number of pods, leaf area, and number of branches. UBC 888 was the most effective primer to identify the genetic diversity of black soybeans that have been given mutation treatments.
\end{abstract}

Keywords: Black soybean, EMS, gamma rays, genetic variation, morphoagronomy.

\section{INTRODUCTION}

Black soybean (Glycine soja) is one of the members of the Leguminosae family [1]. The Ministry of Agriculture and related institutions in Indonesia have released several superior soybean varieties such as Detam, Cikurai, Malika, Mutiara, etc. This research was using Detam 3 variety because it was one of the superior types of a black soybean variety that is still rarely studied. Detam variety has anthocyanin levels of 222.49 mg.100 ${ }^{-1}$, and isoflavone levels (genistein 0.65 $\mathrm{mg} \cdot \mathrm{g}^{-1}$ and daidzein $0.5 \mathrm{mg} \cdot \mathrm{g}^{-1}$ ) [2]. The lack of studies on this variety provides an opportunity for researchers to explore many unknown characters. Besides, Indonesia has a high dependence on imported beans, especially soybeans. In fact, Indonesia has a huge opportunity to increase legume production [3]. Based on data from the Central Statistics Agency (BPS), domestic soybean production was only 982.598 tons. Meanwhile, to meet the domestic needs, Indonesia has to import 2.6 million tons of black soybeans.

The main use of black soybean is for the raw material of soy sauce. At present, black soybeans

\footnotetext{
* Correspondence address:

Shaddiqah Munawaroh Fauziah

Email : shaddiqah_2003@student.ub.ac.id

Address : Dept. Biology, University of Brawijaya, Veteran Malang, 65145.
}

are starting to be considered as raw materials for processing soybeans such as tempe and tofu because of their good content for people with diabetes mellitus [4]. Black soybeans contain anthocyanins, isoflavones, and saponins [5]. Those are antioxidants that play an important role in the regeneration of damaged cells. The more widespread use of black soybean has shown that it is necessary to increase production to meet domestic needs.

Due to low soy production at this time, it is needed to assemble superior varieties of soybeans. The availability of high diversity genetic resources is needed for this purpose. Mutagenesis is one of the ways to expand the genetic diversity of soybeans. Mutagenesis can be done using chemical and physical mutagens. One of the chemical compounds commonly used for mutagenesis is Ethyl Methane Sulfonate (EMS), while gamma rays are often used for physical mutations [6].

Research by Hanafiah on mutations in soybean varieties Agromulyo using $200 \mathrm{~Gy}$ treatment gamma-ray irradiation produced the highest diversity plants [7]. Gamma rays irradiation with the strength of $250 \mathrm{~Gy}$ was also gave an effect of increasing growth in almost all parameters of observation (shoot length, roots, fresh weight and leaf dry weight) to the Canscora decurrens plant [8]. 
EMS causes mutations at the DNA level by changing DNA bases (causing point mutations). It made slight damage to chromosomes, so it is beneficial in plant breeding activities [9]. Point mutations are also passed down to the next generation [10]. Whereas, soybean seeds soaked in $20 \mathrm{mM}$ EMS for 10 hours produced soybean mutants with a total number of pods, contents, pod weight before drying, pod weight after drying, number of seeds, the weight of planting seeds, and weight of 100 seeds [11]. EMS mutagens can also be used at $0.05 \%$ to $2.5 \%$ concentration with 3 to 24 hours of soaking time $[12,13]$.

Evaluation and characterization of mutant crops requires a long time and generally limited to morphological, anatomical, and biochemical characters. Therefore, it needs to do an efficient method that is not dependent on plant development [14]. Molecular characterization can be used to accelerate the process of crop selection. One of molecular the markers commonly used to detect polymorphism is Inter Simple Sequence Repeat (ISSR). ISSR is an effective technique in the genetic analysis of plant breeding programs. ISSR marker provides a quick method, low cost, and requirement for only small quantities of DNA [15], no need for DNA sequence information before amplification, high stability, and abundance of genomic information [16]. The percentage of Soybean's DNA polymorphism by using ISSR marker is about 70100\% [17].

Combination of gamma-ray irradiation and EMS as mutagen is still rarely applied to soybean plants. Previous research showed that EMS and gamma rays can increase the frequency of mutations Chlorophyll and sterile pollen in soybean MAUS-71 and JS-335 variety. [18]. Based on these facts, it was needed to observe the morphoagronomy character and genetic diversity in black soybeans induced by gamma-ray irradiation and EMS by using ISSR.

\section{MATERIAL AND METHOD}

Seeds of black soybean (Detam 3) were obtained from Research Institute for Various Nuts and Tubers (Balai Penelitian Tanaman Aneka Kacang dan Umbi - BALITKABI). This research was using a Completely Randomized Design (CRD).

\section{Induction of Mutation by EMS}

EMS $1 \%$ was dissolved it in Sodium phosphate buffer solution $(\mathrm{pH} 7)$ and DMSO $4 \%$. The treatment was carried out at room temperature [19].

\section{Induction of Mutation by Gamma Rays Irradiation}

Black Soybeans were irradiated by $1000 \mathrm{~Gy}$ dose of gamma rays. We used CO-60 Gammacell 220 irradiator (dose 4585.5 Gy.hour $^{-1}$ ) at the National Nuclear Energy Agency of Indonesia (BATAN).

Table 1. Treatment Detail

\begin{tabular}{|c|c|c|}
\hline $\begin{array}{l}\text { Treatment } \\
\text { Code }\end{array}$ & Treatments & $\begin{array}{l}\text { Number } \\
\text { of seeds }\end{array}$ \\
\hline \multicolumn{3}{|l|}{ Control } \\
\hline $\begin{array}{l}\text { T0-without } \\
\text { mutation }\end{array}$ & $\begin{array}{l}\text { Seeds soaked in phosphate } \\
\text { buffer } \mathrm{pH} 7 \text { for } 6 \text { hours. }\end{array}$ & 15 \\
\hline $\begin{array}{l}\text { T1-without } \\
\text { mutation }\end{array}$ & $\begin{array}{l}\text { Seeds were planted without } \\
\text { soaking. }\end{array}$ & 15 \\
\hline \multicolumn{3}{|c|}{ Gamma rays irradiation } \\
\hline T2-1000Gy & $\begin{array}{l}\text { Seeds were irradiated by } \\
1000 \text { Gy of gamma rays. }\end{array}$ & 100 \\
\hline \multicolumn{3}{|l|}{ EMS } \\
\hline T3-1\% & $\begin{array}{l}\text { The seeds are soaked with } \\
\text { pH } 7 \text { phosphate buffer for } 6 \\
\text { hours, then soaked in EMS } \\
1 \% \text { for } 6 \text { hours. }\end{array}$ & 100 \\
\hline \multicolumn{3}{|l|}{ Combination } \\
\hline T4-1000Gy+1\% & $\begin{array}{l}\text { The seeds were irradiated } \\
\text { with } 1000 \text { Gy gamma rays, } \\
\text { then soaked in } \mathrm{pH} 7 \\
\text { phosphate buffer for } 6 \\
\text { hours, and soaked in EMS } \\
1 \% \text { for } 6 \text { hours. }\end{array}$ & 100 \\
\hline
\end{tabular}

\section{Planting Induced Mutations Seeds}

The planting media used in this research was $3 \mathrm{~kg}$ of soil and sand with 1:1:1 of compost addition to each polybag. A total of $3 \mathrm{~kg}$ media was calculated from the weight of tillage per one hectare that is 2 million $\mathrm{kg}$, and the optimum population of soybean per hectare that is 255.000 plants $[20,21]$. The media watered when the field capacity was $100 \%$ before use. A soybean seed planted in each polybag at $\pm 3 \mathrm{~cm}$ depth and carried out simultaneously until the harvest time.

\section{Observation of Genetic Diversity DNA Isolation, Purification and Quantification}

The third or fourth apical leaf of black soybean was used for DNA isolation by using Doyle and Doyle protocol [22] with modification. DNA purity and concentration were determined using nanodrop (Nano 200-1002).

\section{Electrophoresis}

Electrophoresis was running at constant voltage $60 \mathrm{~V}$ for 60 minutes in $1 \mathrm{x}$ TBE buffer $\mathrm{pH}$ 8.0. The agarose gel used for DNA genome was $1 \%$ and $1.5 \%$ for PCR product. DNA ladder 
(Promega) 100-1000 bp were used as the molecular size standards.

\section{DNA Amplification by Using ISSR Marker}

The components of the PCR reaction mixture and ISSR primers were used for this study can be seen in Table 2. The PCR reaction was performed using BioRad Thermal Cycler (Fig. 1).

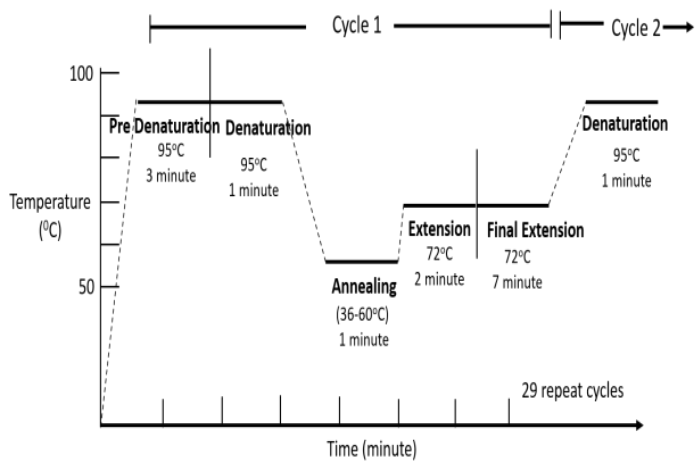

Figure 1. The PCR reaction

\section{Morphoagronomy Character Observation}

The morphoagronomy character observed were plant height $(\mathrm{cm})$, seed weight $(\mathrm{g})$, number of branches, number of pods, number of leaves, and leaf area. These characters were observed 30 days after harvest time.

\section{Data Analysis}

The data of morphoagronomy character of black soybeans were analyzed by using one way ANOVA then followed by DMRT test at $5 \%$ level to find out the best treatment of mutation induction. The ISSR product was scored for each primer then followed by the calculated percentage of polymorphism band. Statistical analysis was performed using the Paleontological Statistics Software Package for Education and Data Analysis (PAST). Dendogram was made via Un-weighted Pair Group Method with Arithmetic Average (UPGMA).

\section{RESULT AND DISCUSSION DNA Amplification}

The result of DNA amplification using ISSR markers (Fig. 2) informs that there was a new DNA band appeared in the mutants, which where missing in the control. The different sizes of the DNA band indicated a change in the nitrogenous base as the result of mutation. When there is a mutation of DNA, the primer that initially attached to this site could not recognize it. The primer either did not attached to the initial site or attached to the new site formed by mutation. The amplification of this new site resulted in a new band with different sizes and thicknesses, so it made a polymorphism.

There were 45 fragments amplified from four primers. The number of fragments produced from each primer varies between 9-14 fragments. The result of polymorphic percentage ranged from $58.33-92.86 \%$. ISSR3 produced the lowest polymorphic percentage (58.33\%), and UBC888 has the highest value (92.86\%) (Table 2).

The highest value of PIC, EMR and MI were generated by UBC888, the lowest value of PIC and $\mathrm{MI}$ were indicated by ISSR3, and the lowest values of EMR and RP were resulted by UBC889 (Table 2). PIC Values for dominant markers were between $0.0-0.5$. The higher the PIC value, the better was the primer in determining genetic variation [22]. The EMR value is used to determine the number of polymorphic fragments in the observed sample. The higher EMR value showed the more effective primer in produce polymorphic fragments [23]. The MI value is used to determine the primer index in producing polymorphic fragments [24]. The RP value is used to determine the strength of a primer in producing a clear fragment. The higher the value of $\mathrm{Rp}$, the better a primer in producing clear fragments [25].

\section{Phylogenetic analysis}

The similarity between Detam 3 and three other mutant varieties was based on the result of primer amplification. Phylogenetic analysis between accessions using PAST software were presented in a dendogram expressed by similarity value (Fig. 3). This result was calculated from three replication of each treatment except the control.

Tabel 2. ISSR primer amplification, \% polymorphism of mutant soybean through gamma rays and EMS induction

\begin{tabular}{rlrrrrrrrrr}
\hline No & primer & & Ta $\left({ }^{\circ} \mathrm{C}\right)$ & \multicolumn{1}{c}{ TNB } & NPB & PB(\%) & PIC & \multicolumn{1}{c}{ EMR } & \multicolumn{1}{c}{ MI } & RP \\
\hline $\mathbf{1}$ & UBC889 & 5"-DBDACACACACACACAC-3" & 53.0 & 9 & 6 & 66.67 & 0.45 & 4 & 1.80 & 11.82 \\
$\mathbf{2}$ & ISSR3 & 5"-GTGTGTGTGTGTGTAC-3" & 50.0 & 12 & 7 & 58.33 & 0.41 & 4.08 & 1.67 & 17.09 \\
$\mathbf{3}$ & UBC876 & 5"-GATAGATAGACAGACA-3" & 52.0 & 10 & 8 & 80 & 0.43 & 6.4 & 2.73 & 13.82 \\
$\mathbf{4}$ & UBC888 & 5"-BDBCACACACACACACA-3" & 53.0 & 14 & 13 & 92.86 & 0.49 & 12.07 & 5.93 & 15.82
\end{tabular}

Notes: TNB: Total Number Band, NPB: Number Polimorphic Band, PB: Polimorphic Band, PIC: Polymorphic Information Content, EMC: Effective Multiple Ratio, MI: Marker Index, RP: Resolution Power 

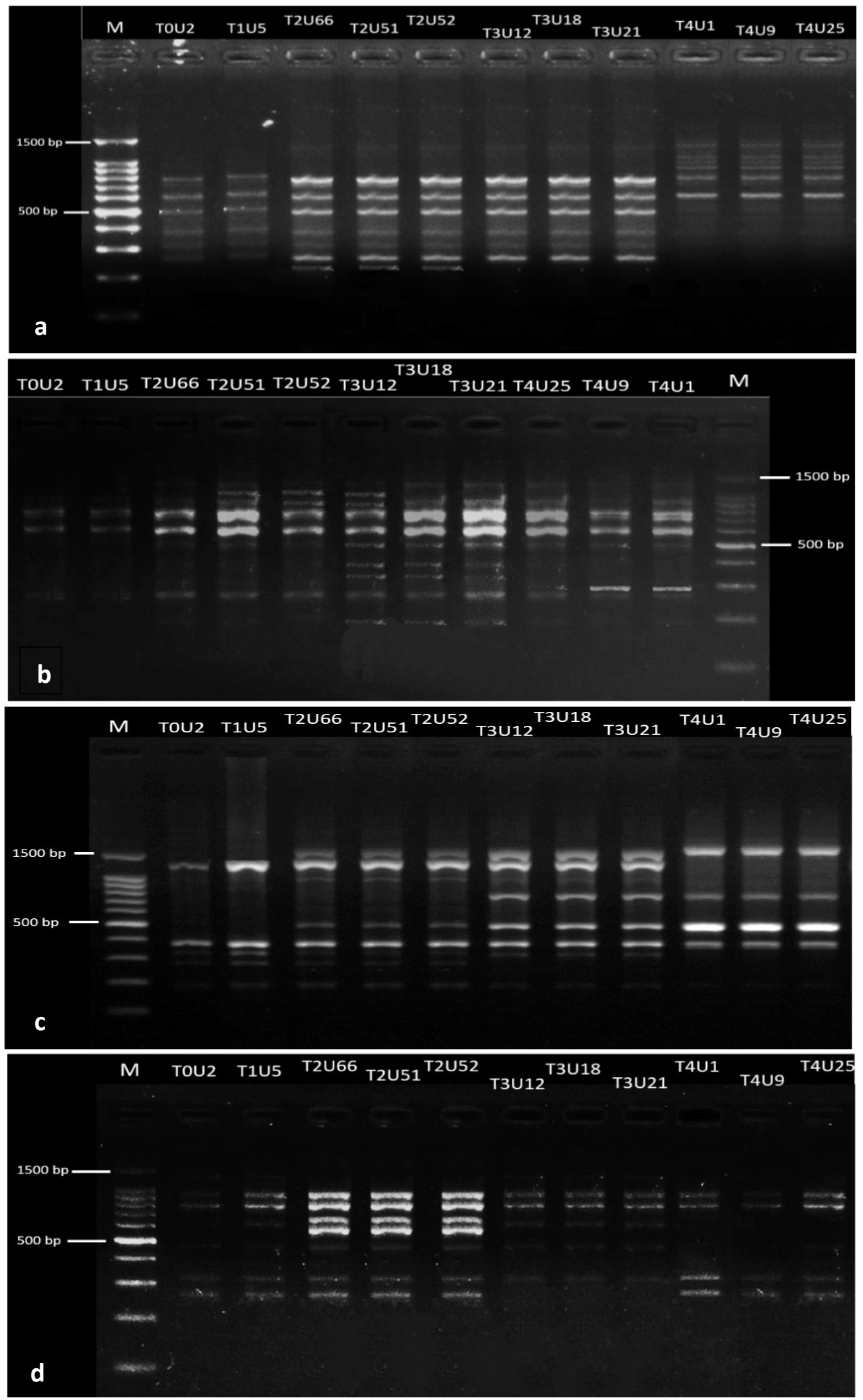

Figure 2. Profile of DNA amplification band for each primer (a) UBC 888, (b) ISSR3, (c) UBC876, (d) UBC889.

Description: ${ }^{*} \mathrm{~T}=$ treatment, $\mathrm{U}=$ replication. $\mathrm{TO}=$ planted without mutation (Seeds soaked in phosphate buffer $\mathrm{pH} 7$ for 6 hours), $\mathrm{T} 1=$ planted without mutation (Seeds were planted without soaking), $\mathrm{T} 2=1000 \mathrm{~Gy}, \mathrm{~T} 3=1 \% \mathrm{EMS}, \mathrm{T} 4=$ $1000 \mathrm{~Gy}+1 \%$ EMS. 

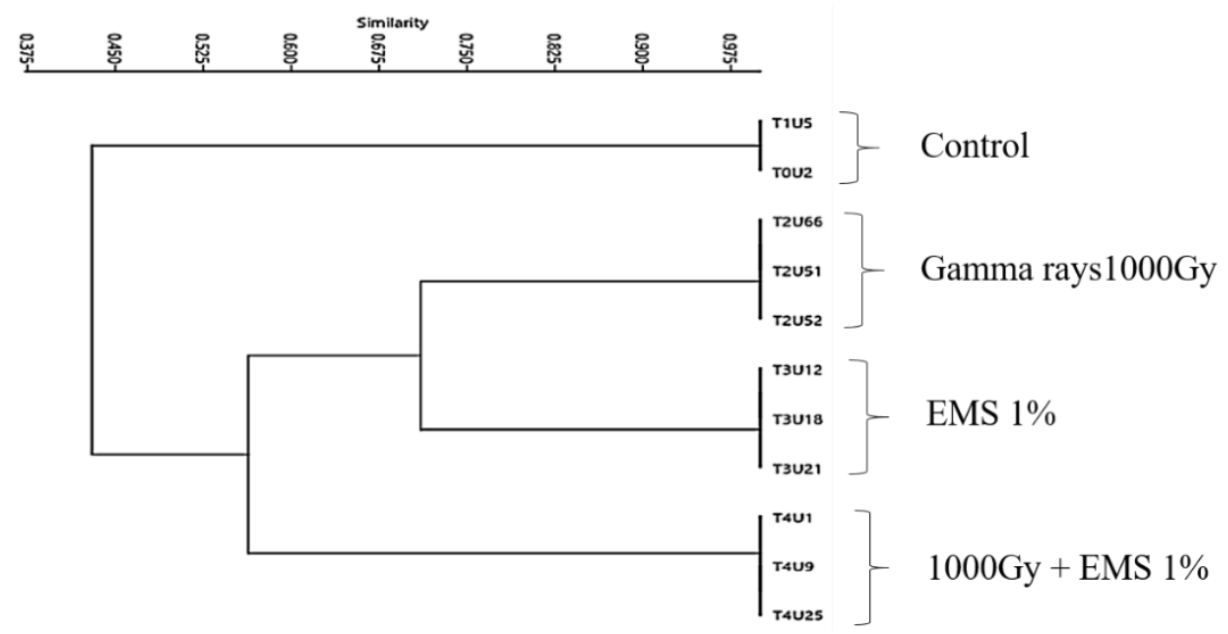

Figure 3. A dendogram of black soybeans (Detam 3 ) mutated by gamma rays and EMS

Description: ${ }^{*} \mathrm{~T}=$ treatment, $\mathrm{U}=$ replication. $\mathrm{TO}=$ planted without mutation (Seeds soaked in phosphate buffer $\mathrm{pH} 7$ for 6 hours), $\mathrm{T} 1=$ planted without mutation (Seeds were planted without soaking), $\mathrm{T} 2=1000 \mathrm{~Gy}, \mathrm{~T} 3=1 \% \mathrm{EMS}, \mathrm{T} 4=$ $1000 \mathrm{~Gy}+1 \%$ EMS.

The similarity of each treatment can be determined by the genetic coefficients. The genetic coefficient value was about 0 to 1 . The closer value to 1 means the more similar genetically, and vice versa [26].

The dendogram in Figure 3 showed that between the control and others, there was a 0.425 similarity value. The sample of combination treatment has 0.55 in similarity with EMS and Gamma rays irradiation. And between the sample of gamma rays and EMS treatment has 0.69 similarity value. It showed that both EMS and gamma rays irradiation were effective methods to increase the genetic diversity of Black Soybeans.

Analysis of mutation treatment by EMS and Gamma rays irradiation showed changes in each treatment. It was caused by the change of DNA sequences so that the primer attachment site changed too. The research by Selvarasu showed that ISSR markers were able to show polymorphisms in Gloria superba plants induced by mutagens [27]. Aswandi also carried out research on the Solanum lycopersicum plant and reported that ISSR was a reliable primer for the initial and screening of mutagen [28].

\section{Analysis of the effect of gamma ray irradiation} and EMS on black soybean morphoagronomy

Morphoagronomy parameters observed in this study were plant height, seed weight, number of leaves, number of pods, and number of branches. Based on the analysis of variance (ANOVA), it was shown that all parameters observed had an $F_{\text {count }}>F_{\text {table }}$ of $5 \%$ level, which means that there was an effect of gamma-ray and EMS treatment on the morphoagronomy of black soybean plants. The significantly different results were further tested by Duncan Multiple Range Test (DMRT) on a 5\% level (Table 3).

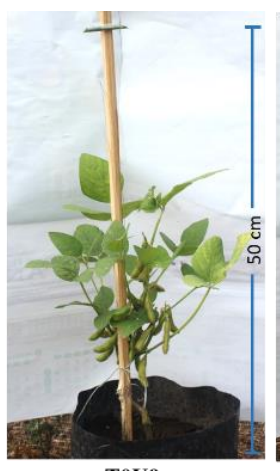

T0U9

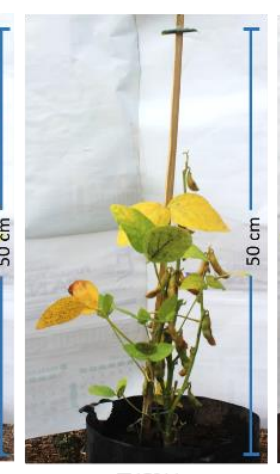

T1U11

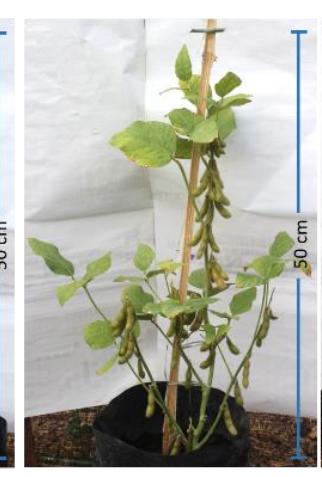

T2U81

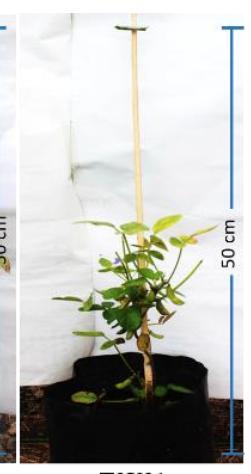

T3U31

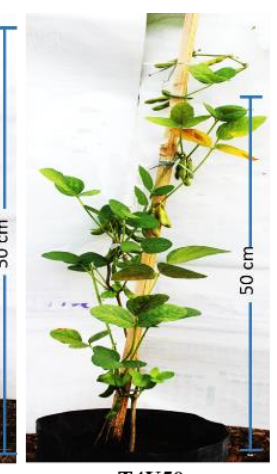

T4U50

Figure 4. Habitus of Mutant Black Soybean Plants

Description: ${ }^{*} \mathrm{~T}=$ treatment, $\mathrm{U}=$ replication. $\mathrm{TO}=$ planted without mutation (Seeds soaked in phosphate buffer $\mathrm{pH} 7$ for 6 hours), $\mathrm{T} 1=$ planted without mutation (Seeds were planted without soaking), $\mathrm{T} 2=1000 \mathrm{~Gy}, \mathrm{~T} 3=1 \% \mathrm{EMS}, \mathrm{T} 4=$ $1000 \mathrm{~Gy}+1 \%$ EMS. 


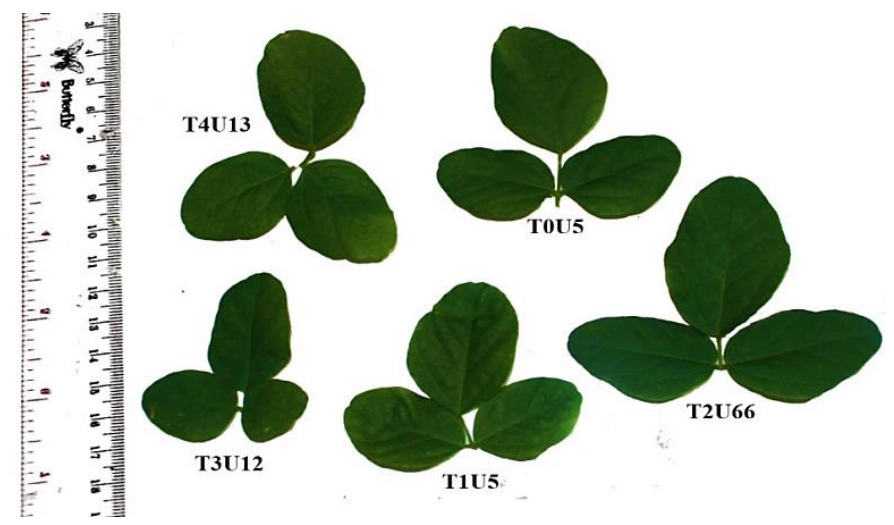

Figure 5. Leaf Area of Mutant Black Soybean Plants

Description: ${ }^{*} \mathrm{~T}=$ treatment, $\mathrm{U}=$ replication. $\mathrm{TO}=$ planted without mutation (Seeds soaked in phosphate buffer $\mathrm{pH} 7$ for 6 hours), T1= planted without mutation (Seeds were planted without soaking), T2=1000Gy, T3=1\% EMS, T4= $1000 \mathrm{~Gy}+1 \%$ EMS.

Tabel 3. Gamma rays irradiation and EMS effect to morphoagronomic character

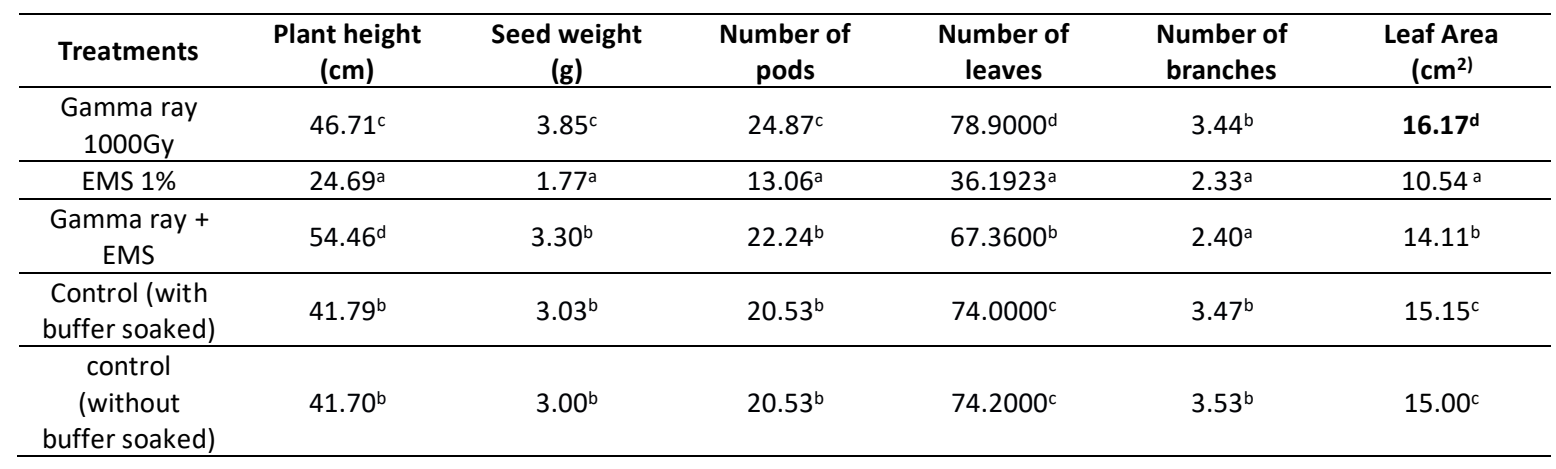

*numbers were followed by the same notation of DMRT (5\%) means not significantly different

The plant height, leaf area, and the number of leaves of black soybean plants treated with gamma-ray irradiation and EMS were varied. The seed weight and the number of pods indicate that the treatment combination had the same effects as the control treatment. The number of branches in black soybeans treated with EMS and combination treatment tends to be the same. Table 3 showed that the EMS treatment caused a decrease in all quantitative variables. This result was in line with Wahyudhi, who reported that EMS could cause a decrease in the growth of Gogo rice seedlings [29].

Based on the result of this study, gamma rays tend to have a positive effect compared to other treatments. It has the same result with Meliala's research that gamma-ray treatment increased phenotypic diversity and plant height in upland rice [30]. Ragapadmi also reported that treatment with EMS has the ability to damage cells more than gamma-ray irradiation [31]. According to Astuti, gamma rays irradiation at certain doses can stimulate plant growth [32].
The growth was due to loss of meristem cell ability in devicied so that the cell activity was increased.

Gamma rays are short electronic waves with a high-energy level that can bind into atoms or molecules to produce free radicals in plant cells. Mutation induction using gamma rays irradiation produced the most mutants (around 75\%) compared to other treatments such as chemical mutagens [33]. The diversity caused by mutagens was different in each species and even varieties. It can have both positive and negative effects depending on the concentration and duration of immersion given due to differences in genetic material and tolerance in responding to mutagen.

\section{CONCLUSION}

Gamma rays and EMS were able to produce genetic diversity in black soybeans Detam 3 varieties. UBC 888 was the most effective primer to identify the genetic diversity of black soybeans that have been given mutation treatments. 
Gamma rays 1000 Gy were more effective in improving morphoagronomy.

The limitation of this research was the lack of mutagen dosage variation. For future study, it needs to use more doses of gamma rays and EMS. It is also a need to use more primers and specific genes to determine gene to determine the genetic diversity in mutated plants.

\section{ACKNOWLEDGEMENT}

The first author is highly acknowledging the supporting Department of Biology, Faculty of Science and Technology, UIN Maulana Malik Ibrahim Malang and Department of Biology, University of Brawijaya.

\section{REFERENCES}

[1] Johnson, H.W., R.L. Bernard. 1963. Soybean genetics and breeding. In: Norman, A.G. (Ed). The Soybean. Academic Press Inc. New York. 1-73.

[2] Nurrahman, M. Astuti, Suparmo, M.H.N.E. Soesatyo. 2012. Pertumbuhan jamur, sifat organoleptik dan aktivitas antioksidan tempe kedelai hitam yang diproduksi dengan berbagai jenis inokulum. agriTech. 32(1). 60-65.

[3] Fachruddin. 2000. Budidaya Kacangkacangan. Kanisius. Yogyakarta.

[4] Zakaria, F.R., D.P.R. Firdaus, N.D. Yuliana. 2016. Konsumsi tahu kedelai hitam untuk memperbaiki nilai sgot/sgtp dan aktivitas antioksidan plasma penderita diabetes tipe 2. Pangan. 25(2). 95-104.

[5] Irwanto, R., D.R. Adawiyah, F.R. Zakaria. Peran fisiologis sari kedelai hitam diperkaya mikroenkapsulan minyak sawit mentah pada penderita diabetes melitus tipe 2 . Jurnal Teknolologi dan Industri Pangan. 27(1). 1-9.

[6] Wiartana, I M.A. 2014. Induksi variasi cabai merah (Capsicum annuum L.) dengan ethyl methanesulfonate pada berbagai tingkat waktu perendaman. Master Thesis. Graduate School. Udayana University. Denpasar.

[7] Hanafiah, D.S., Trikoesoemaningtyas, S. Yahya, D. Wirnas. 2010. Induced mutation by gamma rays irradiation to Agromulyo Soybean (Glycine max [L] Merr.) variety. Nus. Biosci. 12. 105-111.

[8] Yadav, V. 2016. Effect of gamma radiation on various growth parameters and biomass of Canscora decurrens Dalz. Int. J. Herb. Med. 4(5). 109-115.
[9] Alcantara, T.P., P.W. Bosland, D.W. Smith. 1996. Ethyl methane sulfonate induced mutagenesis of Capsicum annuum. J. Hered. 239-241.

[10] Jabeen, N., B. Mirza. 2004. Ethyl methanesulphonate induces morphological mutations in Capsicum annuum. Int. J. Agri. Biol. 6(2). 340-345.

[11] Lukmaningtias, S.A. 2014. Pengaruh mutasi dengan Ethyl Methane Sulfonate (EMS) terhadap Pertumbuhan, Hasil dan kandungan karbohidrat tanaman kedelai (Glycine max L. Merrill). Thesis. Study Program of Agrotechnology, Faculty of Agriculture. University of Jember.

[12] Khan Z., H. Gupta, M.Y.K. Ansari, S. Chaudhary. 2009. Methyl methanesulphonate induced chromosomal variations in a medicinal plant Cichorium intybus L. during microsporogenesis. Toxeminar-1. Biology and Medicine. 1(2). 66-69.

[13] Priyono, A.W. Susilo. 2002. Respon regenerasi in vitro eksplan sisik mikro kerk Lily (Lilium longiflorum) terhadap Ethyl methanesulfonate (EMS). Jurnal IImu Dasar. 3. 74-79.

[14] Wardiyati, T., E.L. Arumingtyas, M. Roviq. 2010. Evaluation of Scar18 marker linked to $\beta$-carotene for early screening of mango (Mangifera indica L.) progenies. AGRIVITA. 32(3). 261-270.

[15] Reddy, P.M., N. Sarla, E.A. Siddiq. 2002. Inter Simple Sequence Repeat (ISSR) polymorphism and its application in plant breeding. Euphytica. 128. 9-17.

[16] Wahyuni S., D.H. Xu, N. Bermawie, H. Tsunematsu, T. Ban. 2004. Skrining ISSR primer studi pendahuluan kekerabatan antar jahe merah, jahe empirit dan jahe besar. Buletin TRO XV. 1. 33-42.

[17] Monpara, J., K. Chudasama, V. Thaker. 2017. ISSR studies on small and large seed varieties of Glycine max. J. Opharmacogn. Phytochem. 6(6). 1652- 1656

[18] Satpute, R.A., R.V. Fultambkar. 2012. Effect of mutagenesis on germination, survival and pollen sterility in $\mathrm{M} 1$ generation of soybean (Glycine max (L.) Merrill). Int. J. Recent Trends in Sci. Technol. 2(3). 30-32.

[19] Narayanan, K.R., C.F. Konzak. 1969. Influence of chemical post-treatments on the mutagenic efficiency of alkylating agents. In: Induced Mutation in Plants. IAEA. Vienna. 281-301. 
[20] Harsono, A., Sudaryono, B.S. Santoso. 2006. Maksimalisasi pemanfaatan radiasi matahari secara kultur teknis pada kedelai di lahan kering masam. Annual Report of Balitkabi 2006. Balitkabi. Malang.

[21] Irwan, A.W. 2006. Budidaya tanaman kedelai (Glycine max (L.) Merill). Padjajaran University. Bandung.

[22] Azmat, M.A.B., I.A. Khan, H.M.N. Cheema, I.A. Rajwana, A.S. Khan, A.A. Khan. 2012. Extraction of DNA suitable for PCR application from mature leaves of Mangifera indica L. J. Zheijang Univ. Sci. B (Biomed \& Biotechnol). 213(4). 230-243.

[23] Roldan-Ruiz, I., J. Dendauw, E. van Bockstaele, A. Depicker, M. de Loose. 2000. AFLP markers reveal high polymorphic rates in ryegrasses (Lolium spp.). Mol. Breed. 6. 125-134.

[24] Varshney, R.K., K. Chabane, P.S. Hendre, R.K. Aggarwal, A. Graner. 2007. Comparative assessment of EST-SSR, ESTSNP and AFLP markers for evaluation of genetic diversity and conservation of genetic resources using wild, cultivated and elite barleys. Plant Sci. 173. 638-649.

[25] Prevost, A., M.J. Wilkinson. 1999. A new system of comparing PCR primers applied to ISSR fingerprinting of potato cultivars. Theor. Appl. Genet. 98. 107-112.

[26] Pratiwi, P. 2012. Analisis variasi genetik beberapa populasi Globba leucantha Miq. di Sumatera Barat dengan RAPD. Master Thesis. Sumatera. Andalas University.

[27] Selvarasu, A., R. Kandhasamy. 2017. Molecular and agro-morphological genetic diversity assessment of Gloriosa superba mutants. Eur. J. Med. Plants. 21(1). 1-13.

[28] Aswandy, A.B.K., N. Rawaidah, K.F. Rodrigues, C.B. Eng. 2015. Evaluation of the mutagenic effect of ethyl methanesulfonate on hexokinase nuclear DNA locus of Solanum lycopersicum. Proceeding of Int'l Conf. on Advances in Science, Engg., Technology \& Natural Resources (ICASETNR15).

[29] Wahyudhi A., T. Nurhidayah. 2014. The growth of $\mathrm{M}-1$ seedling generation of the local varieties of upland rice (Oryza sativa L.) treated with mutagen Ethyl Methane Sulfonate (EMS). Jurnal Faperta. 1(2).

[30] Meliala, Jubleam Haris S., Nur Basuki dan Andy Seogianto. 2016. The effect of gamma irradiation on phenotypic changing in upland rice plants (Oryza sativa L.). Jurnal Produksi Tanaman. 4(7). 585-594

[31] Purnamaningsih, R., E.G. Lestari, M. Syukur, R. Yunita. 2011. Evaluasi keragaman galur mutan artemisia hasili radiasi gamma. Jurnal IImiah Aplikasi Isotop dan Radiasi. 6(2). 139146.

[32] Astuti, D., Y. Sulistyowati, S. Nugroho. 2019. Radiosensitivity analysis of gamma ray to induce genetic diversity of high lignin content sorghum. Jurnal IImiah Aplikasi Isotop dan Radiasi. 15(1). 1-6.

[33] Kovacs E., A. Keresztes. 2002. Effect of gamma and UV-B/C radiation on plant cell. Micron. 33. 199-210. 